\title{
Decay-Accelerating Factor Confers Protection Against Complement-Mediated Podocyte Injury in Acute Nephrotoxic Nephritis
}

\author{
Feng Lin, Steven N. Emancipator, David J. Salant, and M. Edward Medof \\ Department of Pathology (FL, SNE, MEM), Case Western Reserve University, Cleveland, Ohio; and Department of \\ Medicine (DJS), Evans Biomedical Research Center, Boston University Medical Center, Boston, Massachusetts
}

\begin{abstract}
SUMMARY: Decay-accelerating factor (DAF or CD55) is one of a set of regulators that function to protect self cells from deposition of autologous C3b on their surfaces. Its relative importance in vivo, however, is incompletely understood. As one approach to address this issue, we induced nephrotoxic serum (NTS) nephritis in wild-type mice and Daf1 gene-floxed mice devoid of renal DAF expression. For these experiments NTS IgG was administered at a dose $(0.5 \mathrm{mg}$ iv) that requires complement for glomerular injury. After 18 hours, renal injury was assessed by proteinuria and by histologic, immunohistochemical, and electron microscopic analyses of kidneys. Fifteen normal and $15 \mathrm{DAF}$-deficient mice were studied. Baseline albuminuria in the Daf1 ${ }^{-1-}$ mice was $115.9 \pm 41.4 \mu \mathrm{g} / \mathrm{mg}$ creatinine as compared with $85.7 \pm 32.3 \mu \mathrm{g} / \mathrm{mg}$ creatinine in their Daf1 ${ }^{+/+}$littermates $(p$ $=0.075$ ). After administration of NTS IgG, albuminuria increased to $2001.7 \pm 688.7 \mu \mathrm{g} / \mathrm{mg}$ creatinine as compared with 799.7 $\pm 340.5 \mu \mathrm{g} / \mathrm{mg}$ creatinine in the controls $(p=0.0003)$. Glomerular histology was similar in Daf1 ${ }^{-1-}$ and Daf1 $1^{+/+}$mice, with essentially no infiltrating leukocytes. In contrast, electron microscopy revealed severe podocyte fusion in the Daf1 $1^{-1-}$ mice but only mild focal changes in the controls. Immunohistochemical staining showed equivalent deposition of the administered (sheep) NTS IgG in the Daf1 $1^{-1-}$ and Daf1 ${ }^{+/+}$animals. This contrasted with marked deposition of autologous murine C3 in the former and minimal deposition in the latter. The results show that DAF is essential physiologically for protecting glomeruli against autologous complement attack initiated by the classical pathway. (Lab Invest 2002, 82:563-569).
\end{abstract}

$D$ ifferent forms of nephrotoxic serum (NTS)induced nephritis in rats and mice have been widely utilized as animal models for human antibodyinduced renal diseases (reviewed in Salant and Cybulsky, 1988). The mechanism of glomerular damage differs, depending on the source and dose of the antibody and the time after antibody administration (Boyce and Holdsworth, 1985; Salant and Cybulsky, 1988). When a low dosage of sheep NTS is given to mice, complement plays a significant role in the early heterologous phase of nephritis (Hebert et al, 1998; Quigg et al, 1998a, 1998b; Schrijver et al, 1988). This has been verified either by depleting serum complement proteins with cobra venom factor (Quigg et al, 1998b) or using C3 or C4 knock-out mice (Hebert et al, 1998). When the dosage of NTS is increased, the disease is in large part antibody mediated, and dependence on complement is diminished (Hebert et al, 1998). During the later autologous phase, especially if accelerated by preimmunization with heterologous IgG, a more fulminant, leukocyte-rich inflammatory lesion is induced (Lloyd et al, 1997).

Received January 14, 2002.

This work was supported by grants R01 AI 23598 (to MEM) and R01 DK30932 (to DJS) from the National Institutes of Health.

Address reprint requests to: Dr. M. Edward Medof, Institute of Pathology, Case Western Reserve University School of Medicine, 2085 Adelbert Road, Room 301, Cleveland, Ohio 44106.E-mail:mxm16@po.cwru.edu
The sheep NTS used in these studies is specific for several podocyte cell surface proteins, including some that are known to be nephritogenic (Chugh et al, 2001). In addition, the proteinuria that develops in the early heterologous phase of glomerular injury induced in mice with low doses of this antiserum is associated with minimal or no leukocyte infiltration (Hebert et al, 1998; Quigg et al, 1998a, 1998b) and is unaffected by leukocyte depletion (DJ Salant, unpublished observations). It is also noteworthy that decay-accelerating factor (DAF or CD55) expression has been documented on human and rat glomerular epithelial cells in culture (Quigg et al, 1989; Schrijver et al, 1988), and DAF mRNA has been detected in podocytes of human kidney biopsy specimens (Abe et al, 1998). These observations suggest the possibility that the low level of complement-dependent injury induced by NTS, despite substantial binding of complement-fixing IgG antibodies to podocyte cell surface antigens, is caused by inhibition of complement activation by complement regulatory proteins.

There are three cell-associated complement regulators expressed in mouse kidneys that function to protect renal cells from autologous complementmediated injury (reviewed in Nangaku, 1998). These regulators are DAF, complement receptor-related protein-Y (Crry), and the membrane inhibitor of reactive lysis (CD59). In the mouse, two genes, Daf1 and Daf2, code for DAF protein (Spicer et al, 1995). DAF protein deriving from the Daf1 gene is predominantly 
glyco-phosphatidylinositol anchored and widely expressed in a distribution similar to that in humans, whereas DAF protein deriving from the Daf2 gene is predominantly transmembrane anchored and restricted in its expression to testis (Lin et al, 2001; Song et al, 1996; Spicer et al, 1995) and splenic dendritic cells (Lin et al, 2001). Previous studies have shown that DAF present in the kidney derives entirely from the Daf1 gene (Lin et al, 2001; Spicer et al, 1995) and that it is expressed at high levels in glomerular capillary walls (Lin et al, 2001).

Crry has been implicated as playing a protective role against renal damage induced at low doses of NTS by findings that proteinuria is diminished in Crry transgenic mice (Quigg et al, 1998a) and in wild-type mice if recombinant soluble Crry protein is administered (Quigg et al, 1998b). It also has been implicated in other models of complement-mediated nephritis in the rat by opposite findings of increased proteinuria if its function is blocked by anti-Crry antibody (5I2) (Nishikage et al, 1995; Nomura et al, 1995). In rats, CD59 has been shown to contribute to protection from renal injury, in that when anti-CD59 blocking antibody (GD1) is coadministered, more serious renal damage develops than in animals given anti-Crry alone (5I2) (Watanabe et al, 2000). Although there is evidence that DAF can prevent complement activation on cultured rat and human glomerular epithelial cells (Quigg et al, 1989) and that it is present on human glomerular podocytes (Bao et al, 2001), the extent to which DAF plays a role in circumventing glomerular injury and the primary mechanism and site of initial damage in NTSinduced nephritis are poorly understood. Here we demonstrate that in the early heterologous phase of the disease, which is uncomplicated by leukocytemediated inflammation, DAF-deficient mice develop severe podocyte injury and proteinuria as a result of intraglomerular complement activation.

\section{Results}

In initial control studies, mouse erythrocytes ( $\left.E^{\mathrm{mo}}\right)$ from Daf1 ${ }^{-/-}$mice and their Daf1 ${ }^{+/+}$littermates were analyzed by flow cytometry to verify that expression levels of Crry and CD59 in the knock-outs were unchanged from those of wild-type animals. As shown in Figure 1, surface levels of the two regulators in the Daf1 ${ }^{-1-}$ animals were unaltered.

In the first set of experiments, baseline albuminuria in the Daf1 ${ }^{-/-}$mice and their Daf1 ${ }^{+/+}$littermates was quantitated. For this purpose, mice were placed in metabolic cages for 18 hours, and samples were collected. Per the protocol described in "Materials and Methods," values were normalized for creatinine. As shown in Figure 2A, the normalized albumin excretion in the Daf1 ${ }^{-1-}$ mice was higher $(115.9 \pm 41.4 \mu \mathrm{g} / \mathrm{mg}$ creatinine, $n=15)$ than in the Daf1 ${ }^{+/+}$littermates (85.7 $\pm 32.3 \mu \mathrm{g} / \mathrm{mg}$ creatinine, $n=15$ ) but did not reach statistical significance $(p=0.075)$.

Next, NTS was administered and urine was collected for a second 18-hour period. As shown in Figure 2B, after NTS injection, albuminuria in the
A

WT

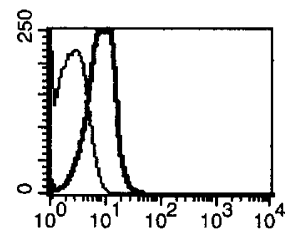

$\mathrm{KO}$

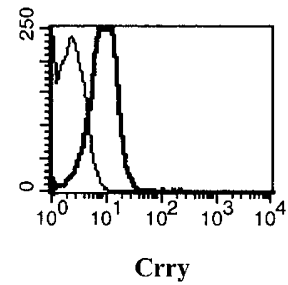

$\mathrm{B}$
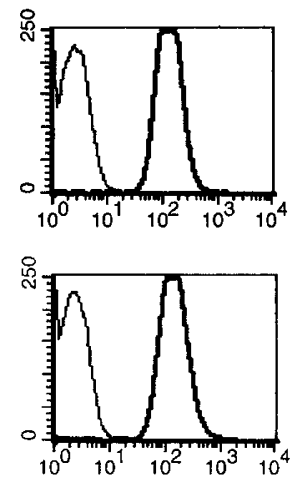

CD59
Figure 1.

Flow cytometry analysis of complement receptor-related protein-Y (Crry) (A) and CD59 (B) expression on mouse erythrocytes $\left(\mathrm{E}^{\mathrm{mo}}\right)$ from Daf1 ${ }^{+/+}$(WT, upper panels) and Daf1 ${ }^{-/-}$(KO, lower panels) mice, respectively, are depicted by the heavy line. Staining with the negative control antibody is shown as the light tracing.

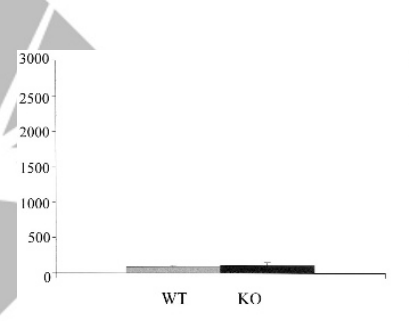

A

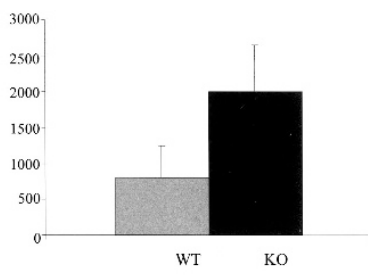

B
Figure 2.

Proteinuria level of wild-type (WT) and Daf1 ${ }^{-1-}$ (KO) mice before (A) and 18 hours after (B) injection of nephrotoxic serum (NTS).

Daf1 $^{-1-}$ mice increased dramatically to $2001.7 \pm$ $688.7 \mu \mathrm{g} / \mathrm{mg}$ creatinine $(n=15)$ as compared with $799.7 \pm 340.5 \mu \mathrm{g} / \mathrm{mg}$ creatinine in the Daf1 ${ }^{+/+}$controls $(p=0.0003)$. Comparable results were obtained in two repeat experiments. There was no significant difference in protein excretion between males and females within either group, either at baseline or after injection of the NTS (not shown).

To evaluate the differences in renal injury that eventuated in the Daf1 ${ }^{-/-}$mice and Daf1 ${ }^{+/+}$controls, immunofluorescence, histologic, and electron microscopic analyses were performed. As shown in Figure $3 A$, immunofluorescent staining showed markedly greater murine C3 deposition in glomeruli of the Daf1 $1^{-1-}$ mice as compared with that in glomeruli of the Daf1 $1^{+/+}$control mice. This contrasted with the results of staining for the administered sheep NTS IgG, in which equivalent intensity and distribution of deposited NTS immunoglobulin was seen in the glomeruli of the knock-out and wild-type mice (Fig. 3B). There was no C3 or sheep Ig staining in either knockout or wild-type mice that were not given injections of NTS.

The comparative histologic appearance of kidney sections from $\mathrm{Daf1}^{-/-}$and $D a f 1^{+/+}$mice is shown in Figure 4. No differences were discernable at the 

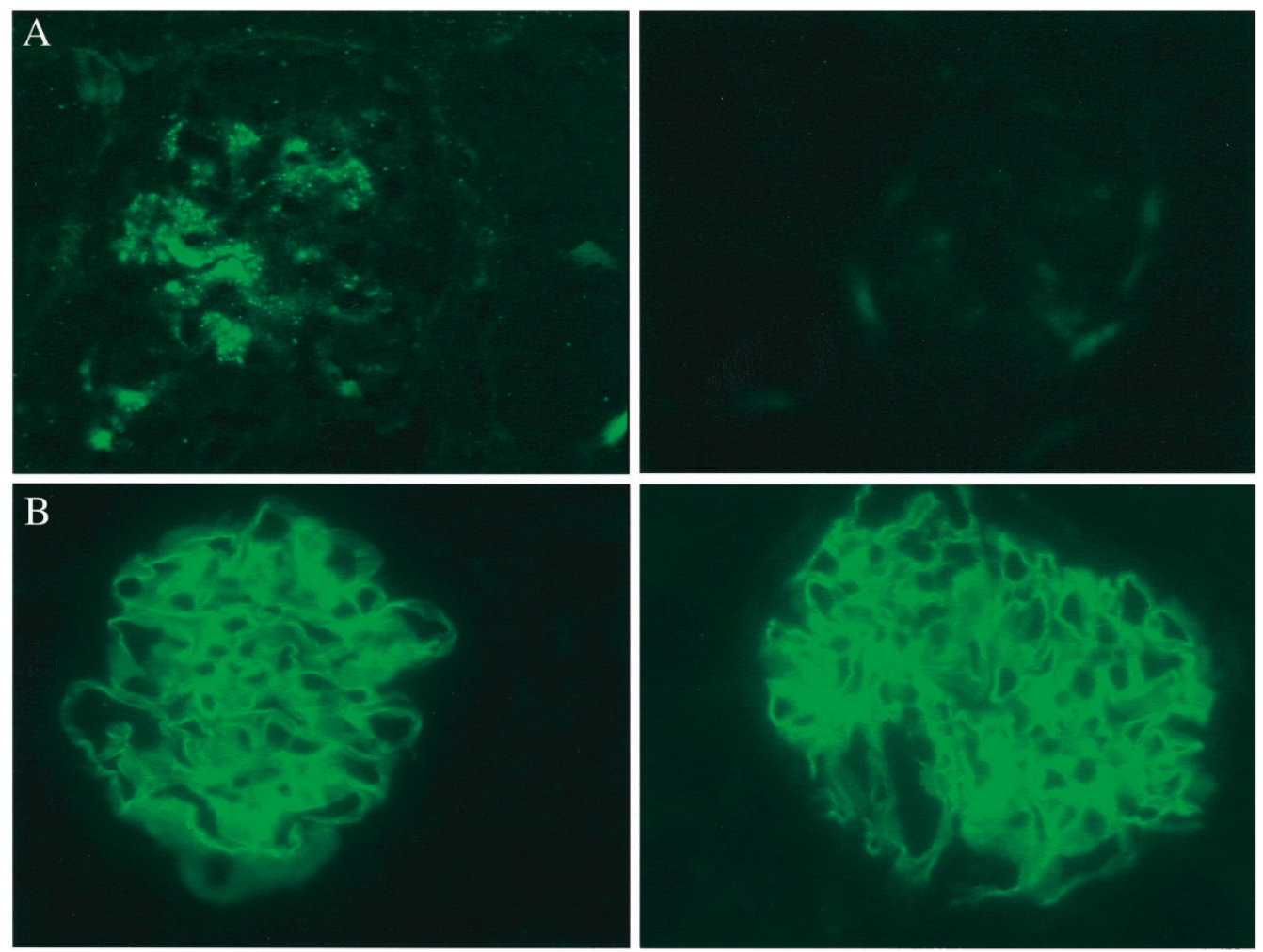

KO

WT

Figure 3.

Immunofluorescent staining for mouse C3 (A) and sheep IgG (B) in glomeruli from knock-out (KO) and wild-type (WT) control mice injected with sheep NTS.
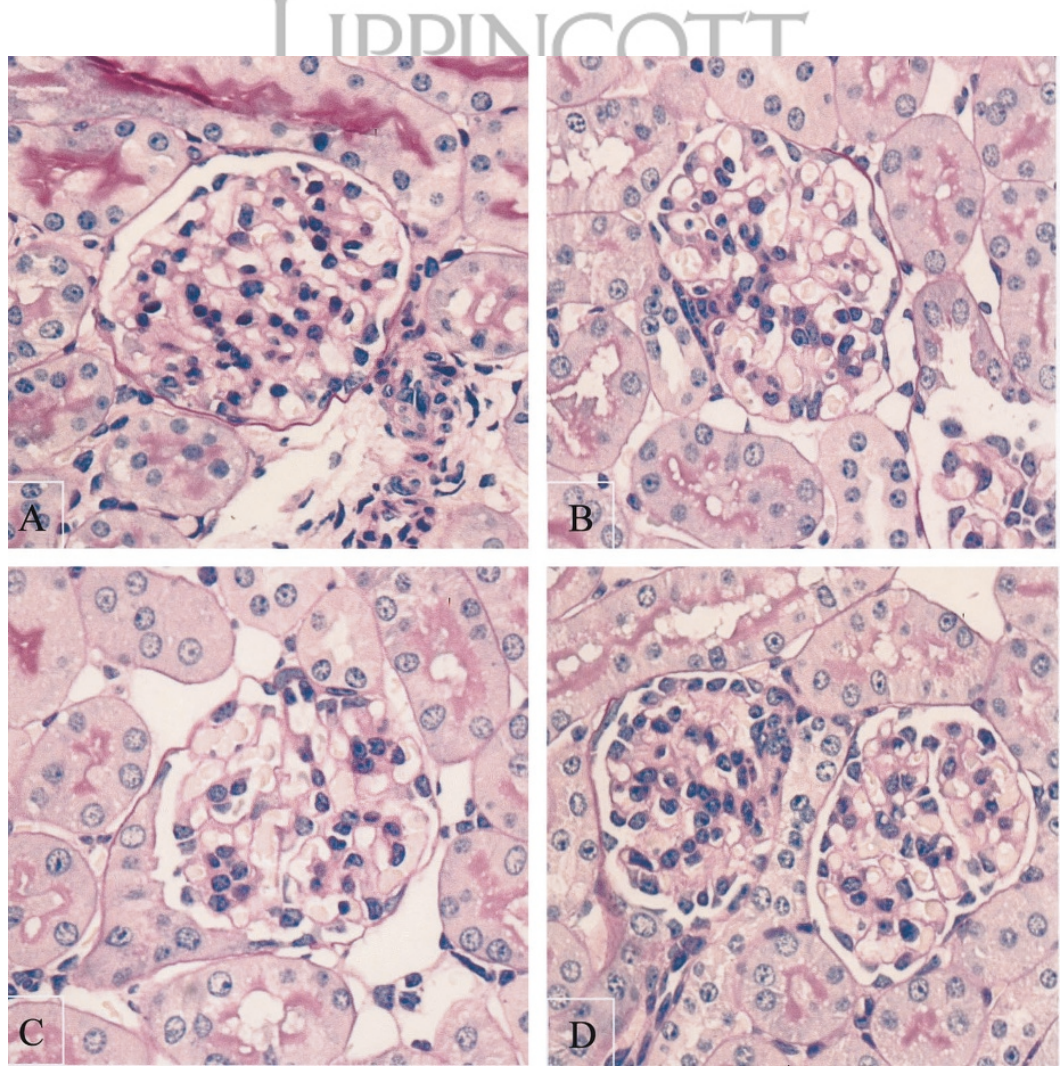

Figure 4.

By light microscopy, glomeruli from wild-type mice (A) appear entirely normal after injection of NTS. Glomeruli from knock-out mice (B, C, and D) do not show significant differences. 
18-hour time point studied. Immunoperoxidase staining for mouse neutrophils disclosed no positive cells in glomeruli or in the tubular interstitium. Moreover, counting of cells in 10 glomeruli from each animal showed no discernable leukocytes in either the Daf1 ${ }^{-\prime-}$ mice or the controls.

The results of the electron microscopic analyses are shown in Figure 5. The Daf1 ${ }^{-/-}$mice showed marked diffuse fusion and flattening of epithelial cell podocytes but only mild segmental abnormalities in the glomerular capillary endothelium and basement membranes. This contrasted with only segmental change in the Daf1 ${ }^{+/+}$littermate controls (Fig. 5). These changes are in accordance with the degree of proteinuria in the knock-out mice as compared with that in the wild-type mice. As expected at this stage in the model, neither electron-dense deposit formation nor leukocyte margination was evident.

As documented above in Figure 1, FACS analyses for Crry and CD59 expression levels on erythrocytes from the $D a f 1^{-1-}$ and Daf1 ${ }^{+/+}$mice showed no significant differences. To confirm that the levels of the two other complement regulators in kidney tissue likewise did not differ, semiquantitative PCR using RNA extracted from kidneys of the animals was performed. PCR additionally was performed to confirm that there was no compensatory expression of DAF protein deriving from the Daf2 gene. As seen in Figure 6 , these analyses, like those of $E^{\mathrm{mo}}$, showed no significant alterations in the expression levels of the other two intrinsic complement regulators. They additionally confirmed that there was no detectable Daf2derived message (not shown).

\section{Discussion}

To protect self tissues from autologous complementmediated injury during complement attack on foreign agents, complement activation is tightly controlled by a system of serum and cell-associated complement regulators. Three cell-associated regulators function intrinsically on the surface membranes of self cells for this purpose. In humans, these intrinsic regulators consist of DAF (Medof et al, 1984), membrane cofactor protein (CD46) (Seya et al, 1986), and CD59 (Davies et al, 1989; Holguin et al, 1989; Okada et al, 1989), all three of which are ubiquitously expressed on almost all cell types. In the mouse, DAF and CD59 are widely distributed on virtually all cells as in humans, whereas membrane cofactor protein is expressed significantly only in the testis. In its place, Crry, a protein unique to rodents (aka 512 antigen in the rat), is ubiquitously expressed. Crry possesses the functions of both DAF and membrane cofactor protein in humans (Kim et al, 1995), calling into question DAF's function in rodents. Reinforcing this question are striking findings that blocking Crry in adult rats induces vascular collapse (Matsuo et al, 1994) and that Crry knockouts cannot be prepared because of massive deposition of C3b on the embryo in early development ( $X u$ et al, 2000). Thus, it has been hypothesized that Crry plays the dominant role in control of the C3 step of complement activation in the mouse, overwhelming the importance of DAF (Quigg et al, 1998a; Quigg and Holers, 1995). The fact that Daf1 knock-out mice are viable, fertile, and show no major abnormalities constitutively (Lin et al, 2001; Sun et al, 1999) has contributed to this view.

In support of the proposition that DAF in fact has physiologic function in mice, in previous studies (Lin et al, 2001) we found higher spontaneous C3 deposition in vivo on $\mathrm{E}^{\mathrm{mo}}$ in $\mathrm{Daf1}^{-1-}$ mice than on $\mathrm{E}^{\mathrm{mo}}$ in their Daf $1^{+1+}$ littermates, despite the presence of Crry on the same cell surfaces. This provided the first evidence that murine DAF function is relevant to complement regulation in vivo. In the NTS nephritis model described here, we present strong evidence in support of the importance of murine DAF's activity in vivo.

During the preparation of this article, a report appeared by Sogabe and associates (Sogabe et al, 2001) that examined the effect of DAF deficiency in a model

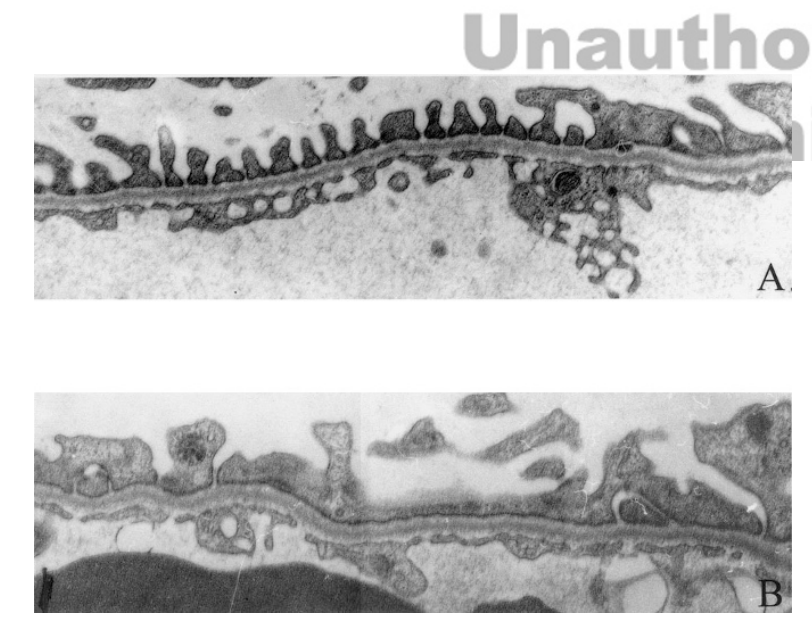

Figure 5.

Electron microscopic examination of glomeruli from wild-type mice given NTS (A) show generally intact epithelial podocytes, with only segmental flattening and fusion (right side of field). In contrast, the epithelial podocytes in the knock-out mice given NTS (B) show extensive flattening and fusion and focal lipid vacuole formation (original magnification, $\times 20,000$ ).

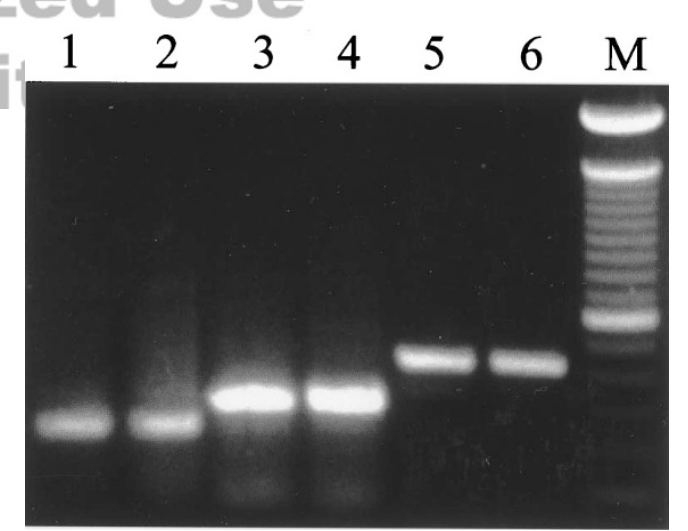

Figure 6.

Semiquantitative RT-PCR analysis of CD59 (lanes 3 and 4) and Crry (lanes 5 and 6) mRNA expression in kidneys from wild-type (lanes 1, 3, and 5) and knock-out (lanes 2, 4, and 6) mice. Mouse actin cDNAs (lanes 1 and 2) were amplified as a control. Lane 1: actin, WT; lane 2: actin, K0; lane 3: CD59, WT; lane 4: CD59, K0; lane 5: Crry, WT; lane 6: Crry, KO; M, 100-bp ladder. The expression of both CD59 and Crry is equal in wild-type and knock-out mice. 
of the accelerated autologous phase of NTS nephritis. Consistent with the findings described in this study, they similarly observed greater susceptibility to glomerular damage in Daf1 knock-out mice relative to wild-type controls despite equal renal expression of Crry. The predominant effect of DAF-deficiency in the studies by Sogabe et al (2001) seemed to be an increase in glomerular cellularity. Albuminuria was absent in the wild-type control mice and was mildly but significantly increased in the knock-out mice. This is consistent with the intense inflammatory response that characterizes the autologous phase of the model and tends to suggest that unregulated activation of $\mathrm{C} 3$ contributed to leukocyte recruitment. Determination of the site of initial complement-mediated injury and pathogenesis of the lesions induced, however, were complicated by the intense cellular inflammatory response that characterizes the later autologous model accelerated by preimmunization.

In contrast, we examined the effect of DAF deficiency on the development of proteinuria in an essentially leukocyte-independent model in which the action of complement is manifest through its cytotoxic action (Boyce and Holdsworth, 1985; Groggel et al, 1985; Hebert et al, 1998; Quigg et al, 1998a, 1998b; Salant and Cybulsky, 1988; Schrijver et al, 1988). Given the location of the target antigens and DAF on glomerular epithelial cells (Chugh et al, 2001; Quigg et al, 1989), the results indicate that the exaggerated proteinuria in Daf1 ${ }^{-1-}$ mice is a result of uninhibited C3 activation, leading to complement-mediated podocyte injury.

As demonstrated in complement-depleted and in C3- and C4-deficient mice (Hebert et al, 1998; Quigg et al, 1998b), and further exemplified by the wild-type controls in this study, proteinuria induced in normal mice with this antiserum in the heterologous phase is partly complement-independent despite the fact that the antiserum is able to activate complement (Salant and Cybulsky, 1988). This is because of tight regulation of complement activation at the level of C3. Thus, when DAF is absent or Crry is neutralized (Nishikage et al, 1995; Nomura et al, 1995), podocytes are exposed to unregulated complement activation, allowing intense C3b deposition, possibly some assembly of C5b-9, and sublethal cytotoxicity. A role of the terminal complement pathway in mediating glomerular injury and proteinuria in the heterologous phase of nephrotoxic nephritis was previously demonstrated in C6-deficient rabbits (Groggel et al, 1985).

With regard to the relative roles of the different complement regulators, Quigg et al (1998a, 1998b) have shown that either injection of soluble recombinant Crry or transgenic overexpression of Crry can ameliorate the glomerular damage in murine nephrotoxic nephritis; Nishikage et al (1995) and Nomura et al (1995) have obtained similar data in other rat models of complement-mediated nephritis with blocking antibodies to Crry. In view of our findings of the critical role that DAF plays in the prevention of complementmediated injury in this model, the relative roles of DAF and Crry in protecting glomeruli from complementmediated injury remain unclear. Based on in vitro studies of the comparative functions of the two proteins in classical and alternative pathway assays (Kraus et al, 2000), we speculate that although Crry may be dominant for regulation of alternative pathway-mediated activation, DAF may be essential for control of classical pathway activation. In the absence of either regulator, sufficient activation, in principle, could occur to overwhelm CD59 regulation at the stage of C5b-9 assembly.

\section{Materials and Methods}

\section{Animals and Antibodies}

Daf1 knock-out mice were developed as previously described (Lin et al, 2001). Briefly, murine GK129 embryonic stem cells were used, and knockout was achieved by Cre/LoxP-mediated deletion. Chimeric mice were bred with the $\mathrm{C} 57 \mathrm{BI} / 6$ strain. Fifteen 8- to 10-week-old Daf1 ${ }^{-1-}$ mice (mixed background) and 15 of their $\mathrm{Daf1}^{+/+}$littermates were used. Equal numbers of males and females were used (see "Results"). The mice were maintained in the Animal Resource Center of Case Western Reserve University. Experiments were performed according to an approved protocol of the Institutional Animal Care and Use Committee.

IgG was purified (by DEAE-Sephacel chromatography) from NTS raised by immunizing sheep with rat glomeruli. The iv-administered dosage providing for injury to mouse glomeruli that is maximally complement dependent was established previously (Salant and Cybulsky, 1988; Schrijver et al, 1988). Rat antimouse Crry mAb was kindly provided by Dr. M. Holers (University of Colorado, Denver, Colorado), and rabbit anti-mouse CD59 IgG was a gift from Dr. B. P. Morgan (University of Cardiff, Cardiff, United Kingdom). FITCconjugated anti-rat $\lg$ and FITC-conjugated antirabbit IgG were purchased from ICN Biochemicals, Inc. (Aurora, Ohio). FITC-labeled goat anti-mouse C3 was obtained from ICN, FITC-labeled rabbit antisheep IgG was purchased from Zymed (San Francisco, California), and FITC-conjugated goat IgG and FITC-conjugated rabbit IgG was purchased from Jackson Immunoresearch (West Grove, Pennsylvania). Purified IgG from rat $\mathrm{mAb} 7 / 4$ specific for mouse neutrophils was obtained from Serotec (Raleigh, North Carolina), and streptavidin-biotin-peroxidase conjugated goat anti-rat IgG (not cross-reactive with mouse Ig) was purchased from Jackson Immunoresearch.

\section{Induction of Nephritis and Quantitation of Albuminuria}

Five hundred micrograms of NTS IgG was injected iv retro-orbitally. Urine samples were analyzed for creatinine and albumin concentrations on a Hitachi/Roche 917 autoanalyzer. The amount of excreted albumin was normalized for the amount of excreted creatinine, and the final value was expressed as micrograms of albumin per milligram of creatinine. 


\section{Immunofluorescence and Histologic Staining}

Kidneys from all mice were harvested 18 hours after injection of NTS. For immunofluorescence staining, samples of kidneys were snap-frozen in liquid nitrogen and cut (at $3 \mu \mathrm{m}$ ) on a cryostat. Cryostat sections were labeled with either FITC-conjugated goat anti-mouse C3 antibody (1:200) or FITC-conjugated rabbit antisheep IgG antibody or with the same concentrations of FITC-conjugated goat IgG or FITC-conjugated rabbit IgG as controls. Stained sections were examined in an Olympus OM6 fluorescence microscope.

Parallel samples of kidney were fixed in 10\% buffered formalin, embedded in Tissue Prep (Fisher Scientific, Fair Lawn, New Jersey), and sectioned at 2 $\mu \mathrm{m}$. Sections were stained with hematoxylin and eosin and periodic acid Schiff and examined with an Olympus $\mathrm{BH} 2$ microscope. Indirect immunoperoxidase staining for mouse neutrophils was performed using rat $\mathrm{mAb} 7 / 4$ as previously reported (Quigg et al, 1998a, 1998b).

\section{Electron Microscopy}

Samples of kidney were fixed in $2.5 \%$ glutaraldehyde and $0.25 \mathrm{~m}$ sodium cacodylate, post-fixed in $1 \%$ osmium tetroxide, and embedded in Spurr's epoxy. Ultrathin (silver-blue) sections were picked up on nickel grids, stained with uranyl acetate/lead citrate, and examined in a JEOL $101 \mathrm{C}$ microscope. At least six $(\times 6700)$ fields from each of at least four glomeruli per mouse were photographed.

\section{Measurement of Crry and CD59 Expression Levels}

One million $\mathrm{E}^{\mathrm{mo}}$ from Daf1/f mice or their Daf1 ${ }^{\mp / f}$ littermates were incubated for 30 minutes on ice with a $10 \mu \mathrm{g} / \mathrm{ml}$ solution of rat anti-mouse Crry mAb or a 1:100 dilution of rabbit anti-mouse CD59 IgG and with the same concentrations of their corresponding nonrelevant controls. After washing, the cells were secondarily incubated for 30 minutes on ice with $5 \mu \mathrm{g} / \mathrm{ml}$ of FITC-labeled anti-rat IgG or FITC-labeled antirabbit lgG, respectively, and the stained cells analyzed on a FACScan flow cytometer (Becton Dickinson, San Jose, California).

\section{PCR Analyses}

Total RNA from kidneys of wild-type and Daf1 knockout mice was extracted using Trizol (Life Technology, Rockville, Maryland). For semiquantitative PCR, identical amounts of total RNA were used to synthesize cDNAs using an oligo dT primer for reverse transcription; PCR was performed for 25 cycles at $94^{\circ} \mathrm{C}$ for 30 seconds, $58^{\circ} \mathrm{C}$ for 30 seconds, and $72^{\circ} \mathrm{C}$ for 60 seconds using the synthesized cDNAs as templates. Mouse Crry cDNA was amplified with primer $P_{1}\left(5^{\prime}\right.$ GAGAATGGCTTGGTACATGTAC $\left.3^{\prime}\right)$ and $P_{2}\left(5^{\prime} G T\right.$ TCTCAGACAGCATGACTGCA $\left.3^{\prime}\right)$; mouse CD59 cDNA was amplified with primer $P_{3}$ (5' GCTTCTGGCTGTGTTCTGTTCC $3^{\prime}$ ) and $P_{4}\left(5^{\prime}\right.$ ATGGCCACCAGAACCGAGGTCC $\left.3^{\prime}\right)$. Mouse actin CDNA was ampli- fied concurrently as a control using primers $P_{5}\left(5^{\prime}\right.$ GTGGGCCGCTCTAGGCACCA 3') and $P_{6}$ (5' TGGCCTTAGGGTGCAGGGGG 3'). Daf1 and Daf2 cDNAs were amplified using primers $P_{8}, P_{9}$, and $P_{10}$ as described (Lin et al, 2001).

\section{Acknowledgements}

The authors thank Ms. Denise Hatala at the CWRU Visual Science Research Center histology core lab (NIH EY11373) for section preparation, Ms. Beth Ann Benetz in the visual science photography lab for help in preparation of the figures, and Ms. Sara Cechner for preparation of the manuscript.

\section{References}

Abe K, Miyazaki M, Koji T, Furusu A, Ozono Y, Harada T, Sakai H, Nakane PK, and Kohno S (1998). Expression of decay accelerating factor mRNA and complement C3 mRNA in human diseased kidney. Kidney Int 54:120-130.

Bao L, St. John PL, Abrahamson DR, and Quigg RJ (2001). Decay-accelerating factor is present on rat glomerular epithelial cells in vivo (Abstract). J Am Soc Nephrol 12:671A.

Boyce NW and Holdsworth SR (1985). Anti-glomerular basement membrane antibody-induced experimental glomerulonephritis: Evidence for dose-dependent, direct antibody and complement-induced, cell-independent injury. J Immunol 135:3918-3921.

Chugh S, Yuan H, Topham PS, Haydar SA, Mittal V, Taylor GA, Kalluri R, and Salant DJ (2001). Aminopeptidase A: A nephritogenic target antigen of nephrotoxic serum. Kidney Int 59:601-613.

Davies A, Simmons DL, Hale G, Harrison RA, Tighe $H$, Lachmann PJ, and Waldmann H (1989). CD59, an LY-6-like protein expressed in human lymphoid cells, regulates the action of the complement membrane attack complex on homologous cells. J Exp Med 170:637-654.

Groggel GC, Salant DJ, Darby C, Rennke HG, and Couser WG (1985). Role of terminal complement pathway in the heterologous phase of antiglomerular basement membrane nephritis. Kidney Int 27:643-651.

Hebert MJ, Takano T, Papayianni A, Rennke HG, Minto A, Salant DJ, Carroll MC, and Brady HR (1998). Acute nephrotoxic serum nephritis in complement knockout mice: Relative roles of the classical and alternate pathways in neutrophil recruitment and proteinuria. Nephrol Dial Transplant 13: 2799-2803.

Holguin MH, Fredrick LR, Bernshaw NJ, Wilcox LA, and Parker CJ (1989). Isolation and characterization of a membrane protein from normal human erythrocytes that inhibits reactive lysis of the erythrocytes of paroxysmal nocturnal hemoglobinuria. J Clin Invest 84:7-17.

Kim YU, Kinoshita T, Molina H, Hourcade D, Seya T, Wagner LM, and Holers VM (1995). Mouse complement regulatory protein Crry/p65 uses the specific mechanisms of both human decay-accelerating factor and membrane cofactor protein. J Exp Med 181:151-159.

Kraus D, Guthridge JM, Marsh HC Jr, and Holers VM (2000). A direct comparison of complement inhibitory capacities of the GPI- and transmembrane forms of mouse DAF to mouse 
Crry and human rsCR1 (Abstract). Immunopharmacology 49:64.

Lin F, Fukuoka Y, Spicer A, Ohta R, Okada N, Harris CL, Emancipator SN, and Medof ME (2001). Tissue distribution of products of the mouse decay-accelerating factor (DAF) genes. Exploitation of a Daf1 knock-out mouse and sitespecific monoclonal antibodies. Immunology 104:215-225.

Lloyd CM, Minto AW, Dorf ME, Proudfoot A, Wells TN, Salant DJ, and Gutierrez-Ramos JC (1997). RANTES and monocyte chemoattractant protein-1 (MCP-1) play an important role in the inflammatory phase of crescentic nephritis, but only MCP-1 is involved in crescent formation and interstitial fibrosis. J Exp Med 185:1371-1380.

Matsuo S, Ichida S, Takizawa H, Okada N, Baranyi L, Iguchi A, Morgan B, and Okada H (1994). In vivo effects of monoclonal antibodies that functionally inhibit complement regulatory proteins in rats. J Exp Med 180:1619-1627.

Medof ME, Kinoshita T, and Nussenzweig V (1984). Inhibition of complement activation on the surface of cells after incorporation of decay-accelerating factor (DAF) into their membranes. J Exp Med 160:1558-1578.

Nangaku M (1998). Complement regulatory proteins in glomerular diseases. Kidney Int 54:1419-1428.

Nishikage H, Baranyi L, Okada H, Okada N, Isobe K, Nomura A, Yoshida F, and Matsuo S (1995). The role of a complement regulatory protein in rat mesangial glomerulonephritis. $\mathrm{JAm}$ Soc Nephrol 6:234-241.

Nomura A, Nishikawa K, Yuzawa Y, Okada H, Okada N, Morgan BP, Piddlesden SJ, Nadai M, Hasegawa T, and Matsuo S (1995). Tubulointerstitial injury induced in rats by a monoclonal antibody that inhibits function of a membrane inhibitor of complement. J Clin Invest 96:2348-2356.

Okada N, Harada R, Fujita T, and Okada H (1989). A novel membrane glycoprotein capable of inhibiting membrane attack by homologous complement. Int Immunol 1:205-208.

Quigg RJ, He C, Lim A, Berthiaume D, Alexander JJ, Kraus D, and Holers VM (1998a). Transgenic mice overexpressing the complement inhibitor crry as a soluble protein are protected from antibody-induced glomerular injury. J Exp Med 188: 1321-1331.

Quigg RJ and Holers VM (1995). Characterization of rat complement receptors and regulatory proteins: CR2 and Crry are conserved, and the C3b receptor of neutrophils and platelets is distinct from CR1. J Immunol 155:1481-1488.

Quigg RJ, Kozono Y, Berthiaume D, Lim A, Salant DJ, Weinfeld A, Griffin P, Kremmer E, and Holers VM (1998b). Blockade of antibody-induced glomerulonephritis with Crry$\mathrm{Ig}$, a soluble murine complement inhibitor. J Immunol 160: 4553-4560.
Quigg RJ, Nicholson-Weller A, Cybulsky AV, Badalamenti J, and Salant DJ (1989). Decay accelerating factor regulates complement activation on glomerular epithelial cells. J Immunol 142:877-882.

Salant DJ and Cybulsky AV (1988). Experimental glomerulonephritis. Methods Enzymol 162:421-461.

Schrijver G, Assmann KJM, Bogman MJJT, Robben JCM, de Waal RMW, and Koene RAP (1988). Antiglomerular basement membrane nephritis in the mouse. Lab Invest 59:484-491.

Seya T, Turner JR, and Atkinson JP (1986). Purification and characterization of a membrane protein (gp45-70) that is a cofactor for cleavage of C3b and C4b. J Exp Med 163:837855 .

Sogabe H, Nangaku M, Ishibashi $Y$, Wada T, Fujita T, Sun X, Miwa T, Madaio MP, and Song WC (2001). Increased susceptibility of decay-accelerating factor deficient mice to anti-glomerular basement membrane glomerulonephritis. J Immunol 167:2791-2797.

Song WC, Deng C, Raszmann K, Moore R, Newbold R, McLachlan JA, and Negishi M (1996). Mouse decay-accelerating factor: selective and tissue-specific induction by estrogen of the gene encoding the glycosylphosphatidylinositol-anchored form. J Immunol 157:4166-4172.

Spicer AP, Seldin MF, and Gendler SJ (1995). Molecular cloning and chromosomal localization of the mouse decayaccelerating factor genes: Duplicated genes encode glycosylphosphatidylinositol-anchored and transmembrane forms. J Immunol 155:3079-3091.

Sun X, Funk CD, Deng C, Sahu A, Lambris JD, and Song WC (1999). Role of decay-accelerating factor in regulating complement activation on the erythrocyte surface as revealed by gene targeting. Proc Natl Acad Sci USA 96:628-633.

Watanabe M, Morita Y, Mizuno M, Nishikawa K, Yuzawa $Y$, Hotta N, Morgan BP, Okada N, Okada H, and Matsuo S (2000). CD59 protects rat kidney from complement mediated injury in collaboration with Crry. Kidney Int 58:1569-1579.

Xu C, Mao D, Holers VM, Palanca B, Cheng AM, and Molina $H$ (2000). A critical role for murine complement regulator Crry in fetomaternal tolerance. Science 287:498-501. 